\author{
HENRY GRAHAM
}

\title{
WHEN THE COMPANY CAUSES HARM: EFFECTIVE CORPORATE SENTENCING IN A JUSTICE SYSTEM BASED ON INDIVIDUAL FAULT
}

\author{
Submitted for the LLB (Honours) Degree
}

Faculty of Law

Victoria University of Wellington

2014 
Table of Contents

I Introduction.

.3

II Rationale for Corporate

Liability.........................................................

III Aims

of

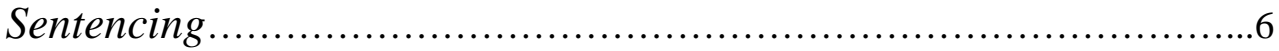

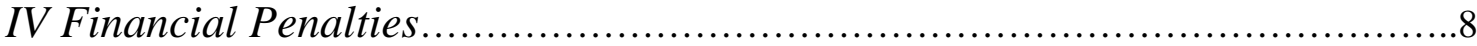

A Determining an $\quad$ Appropriate

Quantity ............................................

B Effect on Companies with Different Wealth Bases......................................10

$V$ Possible Solutions to the Problem of

Insolvency.......................................11

A Mandatory Life Insurance

Coverage....................................................11

B Altering the Order of Pari

Passu......................................................12

C Imposing Financial Penalties in Order to Shame the

Company .13

D Moral Expectation That the Individuals Involved Pay..............................14

$V I$

Non-Financial

Penalties

. .15

A

Formal

Apology

.15

B

Publicity

Order .16

C

Remedial

Order . .17

D Limited Effectiveness of Non-Financial

Penalties .18

VII Imposition of Penalties on Individuals. 
A

Jurisdiction

19

B Legal Expectation That the Individuals Involved Pay...........................20

C Ban Directors from Managing another Company.............................21

D Burden of Proof.......................................................22

VIII

Recommendation

for

Reform

.23

A Application of Law

Reform.................................................24

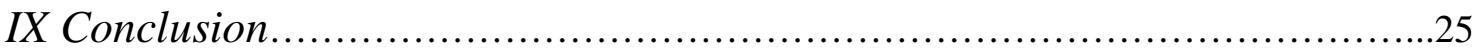

$X$

Bibliography.............................................................26

\begin{abstract}
The imposition of corporate liability is problematic in terms of both conviction and sentencing. Once convicted, it is still difficult to effectively sanction a corporation, as the artificial nature of the entity means it cannot be imprisoned. This problem is illustrated by the Pike River disaster and the relevant corporation's conviction for nine health and safety offences. In that case, the defendant was insolvent, so no effective financial penalty could be imposed. This paper will consider the range of sanctions that could be used to effectively punish a guilty corporate defendant. A starting point for corporate sentencing would be the imposition of a financial penalty (both reparation orders and fines). However, if the company is insolvent, this may be ineffective. There are several mechanisms which could be used to overcome the issue of insolvency, but the court should also consider various non-financial penalties and the imposition of sanctions against individuals. The court may be able to adequately punish a company if a variety of penalties is used.
\end{abstract}

Key Words 


\section{Introduction}

The New Zealand criminal justice system focuses on finding individuals liable and sanctioning at a personal level. ${ }^{1}$ This approach becomes problematic when a corporation is held criminally responsible. ${ }^{2}$ Firstly, at the conviction stage, it is difficult to attribute the elements of an offence to the company. ${ }^{3}$ In addition, even if a company can be convicted, there are also problems at the sentencing stage. It can be challenging to impose an effective sanction. A great deal of literature focuses on the issues with conviction, but less emphasis is placed on the problematic issue of corporate sentencing. ${ }^{4}$ A company is an artificial construct, ${ }^{5}$ but there still needs to be a way to appropriately sentence an entity because it can still cause harm. This problem is particularly evident when a company is responsible for loss of human life. Where this occurs there is substantial public interest to ensure that the corporation takes responsibility for any fault which caused death. Therefore, the courts need to impose a different set of penalties in order to effectively sanction a guilty corporate defendant. This paper focuses on the challenges in sentencing should a corporation be convicted. There will be emphasis on cases that involve the loss of life, as when courts need to sentence an entity convicted of the highest level of harm, many sentencing problems are exacerbated.

The recent case of Department of Labour v Pike River Coal Ltd illustrates the problems inherent in sentencing a corporation and discusses possible solutions. The corporation was involved in negligent and risky practices which led to the deaths of 29 miners. Charges were brought under health and safety legislation (as a charge of corporate manslaughter is currently unavailable in New Zealand). ${ }^{6}$ In the case, sentencing issues were particularly cogent as the company was found responsible for loss of life.

\footnotetext{
${ }^{1}$ Sentencing Act 2002, s 7.

2 The terms "company" and "corporation" are used interchangeably in this paper. The term "legal person” has also been used at times to draw comparisons to a "natural person” (i.e. a human being).

${ }^{3}$ Meridian Global Funds Management Asia Ltd v Securities Commission [1994] 2 NZLR 291 at [7]-[8].

${ }^{4}$ Andrew Ashworth Principles of Criminal Law (6th ed, Oxford University Press, Oxford, 2009) at 152-154.

${ }^{5}$ Companies Act 1993, s 15.

${ }^{6}$ Department of Labour v Pike River Coal Ltd [2014] DCR 32 at [2]-[3].
} 
Wherever serious physical harm is caused, the usual recourse is a sentence of imprisonment. ${ }^{7}$ This is impossible for a corporation. Following the company's nine convictions for breaches of the Health and Safety in Employment Act 1992, Farish J combined a reparation order in the sum of $\$ 3.41$ million to be paid to the victims' families with a fine of $\$ 760,000$ to be paid to the government. ${ }^{8}$ However, the company had become insolvent and could not pay these financial penalties. In a case where the company cannot pay, the judge can exercise discretion and choose not to impose the penalty. ${ }^{9}$ In this case, the judge declined to use this discretion. ${ }^{10}$ She responded by encouraging the directors and shareholders to contribute their own personal funds to cover the debt. ${ }^{11}$ However, this expectation could not be legally enforced and individual members of management refused to contribute. The outcome of the sentencing judgment was that no effective sanction had been placed on the company. ${ }^{12}$ The unsatisfactory outcome in the Pike River case provides the impetus for this paper. If a broader variety of sentencing options were available, the court may have been able to impose a more adequate sanction.

As many sanctions were designed to be imposed only on natural persons, the sentencing of a "legal person" such as a corporation is difficult. Courts are unable to impose a period of imprisonment, ${ }^{13}$ so instead need to develop other sentencing options, including both financial and non-financial penalties. This paper introduces the concept of corporate liability and discusses the rationale for its use. Focus then shifts to an analysis of the various sentencing options. This analysis begins with an examination of possible financial penalties - reparation orders and fines. Difficulties with their use are then assessed. Possible solutions to the specific problem of sentencing an insolvent corporation are examined, then consideration is given to some alternatives to financial compensation. These alternatives focus on restorative justice, social stigmatisation, and ensuring the harm does not reoccur. Focus then shifts to the imposition of penalties directly on to the individuals involved. It is ultimately concluded that a range of financial and non-financial sanctions should be used in conjunction to effectively sentence a company. Further, it is argued that the court should also consider the individual

\footnotetext{
${ }^{7}$ Crimes Act 1961, s 177.

${ }^{8}$ At [41].

${ }^{9}$ Sentencing Act, s 41.

${ }^{10}$ At [40].

${ }^{11}$ At [19]-[20].

12 "Pike River ruling proves need for corporate manslaughter law - unions" ONE News (New Zealand, 5 July 2013) <tvnz.co.nz>.

${ }^{13}$ Criminal Procedure Act 2011, s 6.
} 
circumstances of each company, such as their wealth base, ability to collect money from individuals, whether they are going to continue trading, and if so, whether they can rebrand following conviction.

\section{Rationale for Corporate Liability}

Despite the problems inherent in convicting and sentencing a company as a whole, corporate liability is beneficial in two significant ways. One advantage of allowing a corporation to be convicted of a criminal offence is that it promotes public welfare. It is important to be able to effectively criminalise corporate conduct because harm is still being caused. This public interest is especially applicable where the charges are based on health and safety violations, as these offences involve danger to personal safety. ${ }^{14} \mathrm{~A}$ criminal conviction would stigmatise an entity in a way that a civil claim could not. ${ }^{15}$ The public would be likely to respond to the fact of this conviction and both the reputation and the revenue of the corporation would suffer. This would provide an important incentive for companies to ensure workers are protected. Ross Wilson has argued the using a harsh criminal offence is therefore in the best interests of vulnerable workers. ${ }^{16}$ Companies would have an added incentive to ensure regulations are followed. In addition, public prosecution is beneficial as it removes the need for personal retribution.

Another important reason to attribute criminal liability to a company is the inherent difficulty in finding individuals liable. In some situations, a court can be unable to find individuals guilty and therefore, corporate liability is the only option for ascribing blame. The main problem with finding individual liability is that it can sometimes be too difficult to attribute a causative link from the actions of a single person to the harm caused. ${ }^{17}$ Systemic failures within the company may be the substantial cause of death, and it would be too difficult to attribute blame to one or more individuals. ${ }^{18}$ For example, when the MS Herald of Free Enterprise capsized after launch due to a bow-door being left open, blame could not be

\footnotetext{
${ }^{14}$ Health and Safety in Employment Act 1992, s 6.

${ }^{15}$ Eric Rasmusen “Stigma and Self-Fulfilling Expectations of Criminality” (1996) 39 Journal of Law and Economics 519 at 519-521.

${ }^{16}$ Royal Commission on the Pike River Coal Mine Tragedy Final Overview: Volume 2 (Department of Internal Affairs, October 2012) at 266-269.

${ }^{17}$ RB Whittingham The Blame Machine: Why Human Error Causes Accidents (Elsevier ButterworthHeinemann, United Kingdom, 2004) at 120-121.

${ }^{18} R$ v P \& O Ferries (Dover) Ltd (1991) 93 Cr App Rep 72 (Herald of Free Enterprise).
} 
ascribed to one individual. The second officer was under a duty to shut the door, the first officer was under a duty to check the door was shut, and the captain is traditionally liable for all problems. In that situation, it was only practicable to charge the company as a whole with an offence. ${ }^{19}$

\section{Aims of Sentencing}

Even if the issues with conviction can be adequately addressed, it can still be difficult to impose an effective sentence on a corporation following a finding of guilt. This research focuses on three main possible sanctions: financial penalties, non-financial penalties, and individual penalties. Financial penalties can be imposed, but these may be difficult to administer in situations where the company has become insolvent because they lack capacity to pay. In addition, companies with a large amount of wealth may be able to effectively purchase the right to break the law, as the penalties represent only a small fraction of their wealth base. Non-financial penalties have been imposed in other jurisdictions, such as the United Kingdom, but the adequacy of these penalties is also an issue, especially where the company ceases to trade following the imposition of a sentence. The court could also consider imposing a sentence on the individuals involved, despite the corporation as a whole being convicted. Ideally, these sentencing options should be developed by Parliament, but consideration will be given to mechanisms the court could use within the scope of the current legislation.

In addition, consideration is given to the distinction between sentencing a corporation convicted of a regulatory offence and one convicted of a true crime. Problems with sentencing are always present, but these issues are intensified when the offence involves serious injury or loss of life. Following conviction for a regulatory offence, one of the aforementioned sentencing options may be appropriate. However, the traditional penalty for a more serious crime such as culpable homicide is the imposition of a term of imprisonment and the government has indicated that this is desirable. ${ }^{20}$ This is not available for a corporation. The corporation is an artificial construct designed to assist effective commercial

\footnotetext{
19 The company was charged with manslaughter but was later acquitted.

20 (3 December 2013) 695 NZPD 15118.
} 
practice and therefore, it cannot be imprisoned. ${ }^{21}$ On this basis, one issue with expanding corporate liability to cover serious offences such as manslaughter would be the problem inherent in sentencing a company for this, when true crimes were designed to be committed by only natural people. ${ }^{22}$

Initially, the court should consider the six purposes of sentencing which must be assessed, as different penalties focus on various aims. These are: retribution, denunciation, deterrence, incapacitation, rehabilitation, and restitution. ${ }^{23}$ Retribution and denunciation focus on punishing the defendant and condemning the conduct. ${ }^{24}$ Deterrence focuses on generally discouraging this type of conduct and specifically dissuading the current defendant from reoffending. ${ }^{25}$ Incapacitation seeks to protect society by preventing the defendant from reoffending (where the defendant is a natural person, this is usually through a term of imprisonment or a restrictive community-based sentence). ${ }^{26}$ The aim of rehabilitation is to address the underlying issues and causes of the original offending. ${ }^{27} \mathrm{~A}$ rehabilitative focus can prevent recidivism. ${ }^{28}$ Restitution is the one purpose which focuses on the victim. It seeks to repair the harm and provide the victim with some kind of compensation (either financial or non-financial). ${ }^{29}$

When sentencing a natural person, the court focuses on the relevant aims which best fit the needs of the individual, the victim, and the community. ${ }^{30}$ While imprisoning a natural person may simultaneously achieve all of the purposes of sentencing that the court considers necessary (excluding restitution), this is not possible for a corporation. The different penalties available for corporations focus on different and specific sentencing purposes. Therefore, it is important they are used in conjunction. For example, financial penalties focus on retribution, denunciation, deterrence, and material restitution. The various forms of non-financial penalties can focus more on deterrence, rehabilitation, and non-material restitution.

\footnotetext{
${ }^{21}$ Ross Grantham and CEF Rickett (eds) Corporate Personality in the 20th Century (Hart Publishing, United Kingdom, 1998) at 12-13.

${ }^{22}$ Crimes Act, s 177.

${ }^{23}$ Sentencing Act, s 7.

${ }^{24}$ Sections 7(a), 7(b) and 7(e).

${ }^{25}$ Section $7(\mathrm{f})$.

${ }^{26}$ Section 7 (g).

${ }^{27}$ Section 7(h).

${ }^{28}$ Andrew Ashworth “Responsibilities, Rights and Restorative Justice” (2002) 42 Brit J Criminol 578 at 590592.

${ }^{29}$ Sections 7(c) and 7(d).

30 Sentencing Act, s 8.
} 
Therefore, it is important that both the range of sentences which can be imposed and the range of purposes which need to be met are considered. This consideration allows the court to come up with flexible outcomes which can be tailored to fit the needs of each case. By doing this, the most effective result can be obtained. This paper will consider each of the sentencing options in turn.

\section{Financial Penalties}

The first option to consider when sentencing a corporation is the imposition of a financial penalty. The court has a broad jurisdiction to impose this sanction as section 6 of the Criminal Procedure Act 2011 provides that if an imprisonable offence is committed by a body corporate, the court can impose a financial penalty instead. In addition, this approach is reflected in other jurisdictions, as the starting point for sentencing a company in the United Kingdom is the imposition of a financial penalty. ${ }^{31}$

Two separate forms of monetary penalty could be imposed: reparation and/or fines. Reparation is aimed at providing compensation to the victim(s) and their families. ${ }^{32}$ The focus on the victim helps repair some of the harm that has been caused. Thus the aim of reparation is financial restitution. Fines are aimed at punishing the company and deterring future harmful conduct. ${ }^{33}$ The focus on the offender is a deterrent which contributes to reducing the rate of recidivism. These two forms of reparation should initially be considered separately before the court considers the totality of the financial penalty. ${ }^{34}$

\section{A Determining an Appropriate Quantity}

A primary issue to consider is the inherent difficulty in determining an appropriate quantum of financial penalty to impose. This is because there are a number of both quantitative and qualitative factors that could be taken into account. In Department of Labour $v$ Hanham \& Philip Contractors Ltd, the court offered some guidance on imposing financial sentences. A basic three step methodology is used. The first step involves fixing the amount of reparation.

\footnotetext{
${ }^{31}$ Corporate Manslaughter and Corporate Homicide Act 2007 (England and Wales), s 1(6).

32 Sentencing Act, s 10; Department of Labour v Pike River Coal Ltd, above n 6, at [8]-[9].

${ }^{33}$ Mobile Refrigeration Specialists Ltd v Department of Labour (2010) 7 NZELR 243 (HC) at [10]-[11].

${ }^{34}$ Department of Labour v Hanham \& Philip Contractors Ltd (2008) 6 NZELR 79 (HC) at [33].
} 
The court considers any offers to make amends and the financial capacity of the defendant. Reparation is to be given primacy over fines because the money goes directly to compensating victims and repairing harm. The second step involves fixing the amount of any fine. Here, the court set out three bands of seriousness as a starting point. ${ }^{35}$ Low culpability offences would attract a fine of up to $\$ 50,000$ while for medium culpability offences, a fine between $\$ 50,000$ and $\$ 100,000$ would be appropriate. The court indicated that a fine over $\$ 100,000$ would be expected in cases of high culpability, but the upper limits of this have yet to be determined. The maximum penalties need to be reserved for the worst kind of case. ${ }^{36} \mathrm{~A}$ further issue involves adequately categorising offences into each band of seriousness. This involves a value judgement and each case needs to be decided on its facts.

In addition, the English Sentencing Council has devised a number of non-exhaustive aggravating and mitigating factors that a sentencing judge could use after the initial assessment of seriousness. ${ }^{37}$ Aggravating factors include foreseeability of serious injury, the degree of negligence, the number of injuries, and failure to respond to warnings. Mitigating factors could involve prompt acceptance of responsibility, cooperation with the investigation, and a previously responsible attitude towards health and safety. A sentencing judge in New Zealand could adopt a number of these guidelines when determining an amount.

A further issue arises when setting financial penalties in the case of a more serious offence, such as health and safety offending or corporate manslaughter. There is an inherent difficulty involved in placing a quantitative value on the loss of life or compensating for psychological harm, as both of these factors are qualitative in nature. Farish J admitted that this troubled her when establishing the figures in the Pike River case. ${ }^{38}$ Financial penalties can be more easily imposed when there is some measurable harm caused. For example, in cases of wilful damage or theft, the value of property can be reasonably ascertained using a more simple mathematical formula.

For manslaughter and other serious crimes that involve violation of personal freedoms, the courts generally do not have to make this financial assessment. They usually impose a term of

\footnotetext{
${ }^{35}$ At [51]-[60].

${ }^{36} R$ v Taueki [2005] 3 NZLR 372 (CA) at [25].

${ }^{37}$ Sentencing Guidelines Council Corporate Manslaughter \& Health and Safety Offences Causing Death (February 2010) at 4.

${ }^{38}$ At [8].
} 
imprisonment. ${ }^{39}$ The offender loses a substantial amount of their personal liberty and this is generally seen as a sufficient penalty following the commission of such a serious crime. ${ }^{40}$ However, in cases involving loss of life, it is impossible to specify a term of imprisonment or any other sentence which deprives the offender of their liberty. Here, the artificial nature of the company makes sentencing problematic. Producing an adequate financial penalty is a difficult exercise for any court, as they need to impose a particularly severe financial penalty in order for this to compare to imprisonment. In addition, imposing a fine for culpable homicide may downgrade the seriousness of the offence as offenders face only deprivation of material welfare as consequence. Therefore, it may be beneficial for the court to consider sanctions against the individual directors involved in managing the company despite the company as a whole being the one convicted. Further discussion of individual sanctions is included later in Part VII.

Another serious issue in regard to setting an amount is whether the size of the company should be relevant to the financial penalty imposed. The English Sentencing Council has rejected a fixed correlation between penalty and means of payment as inappropriate on the basis that it could lead to vast discrepancies in quantum of penalty. ${ }^{41}$ The preferred approach is to assess each case on an individual basis by looking at assets, profit, and turnover. The sentencing court can then consider what level of fine inflicts a meaningful punishment. However, linking the size of the company to the amount to be paid can reduce the issue of wealthy companies being able to essentially pay to break the law, as these larger corporations have to pay a greater sum.

\section{B Effect on Companies with Different Wealth Bases}

A major issue with imposing a financial penalty is that a wealthy corporation can effectively purchase the right to break the law. Following conviction, they can simply pay a lump sum. Companies with a large profit may not be significantly deterred from negligent and risky practices if they do not fear the imposition of a financial penalty, especially if the gains from omitting to install safety procedures outweigh any penalty which could be imposed. ${ }^{42}$ This

\footnotetext{
${ }^{39}$ Crimes Act, s 177.

${ }^{40}$ Rajesh Chhana and others The Sentencing Act 2002: Monitoring the First Year (Ministry of Justice, March 2004) at 22-23.

${ }^{41}$ Sentencing Guidelines Council, above n 37, at 5-7.

${ }^{42}$ Sentencing Guidelines Council, above n 37, at 3-4.
} 
may create an unfair distinction between large corporations and small to medium enterprises by giving large corporations the power to avoid satisfactory legal sanctions.

On the other hand, companies with very little profit and companies who have become insolvent may not be able to pay any financial penalties involved. A company is deemed insolvent if one of two conditions are met: either the company is unable to pay its debts as they become due in the normal course of business or the value of the company's assets is greater than the value of its liabilities, including contingent liabilities. ${ }^{43}$ If a company is insolvent, they lack capacity to pay any financial penalties imposed.

This is problematic as these financial penalties would only be effective if the company had the capacity to pay them. If the company does not (as was the case in Department of Labour $v$ Pike River Coal Ltd), they can simply ignore the sentence imposed and the court has no legal recourse. Thus, very unprofitable companies can avoid financial sanctions entirely. If an insolvent company can avoid paying financial penalties, not only can they evade effective sanctions, but the government could be called upon to fund any required compensation. ${ }^{44}$ Therefore, it is important to consider the various ways courts could impose operative financial penalties when the company is insolvent.

\section{Possible Solutions to the Problem of Insolvency}

\section{A Mandatory Life Insurance Coverage}

A possible solution for the issue of imposing financial penalties on insolvent companies would be to institute a certain amount of mandatory life insurance coverage, which each company must pay for. Following the Pike River disaster, Kevin Hague branded the company's life insurance coverage of $\$ 2$ million as "totally inadequate". ${ }^{45}$ This approach would ensure that companies cannot avoid liability because their life insurance coverage is unsatisfactory and would seek to pre-emptively address the issue of insolvency. It also guarantees families receive compensation. However, this requirement may be seen as too

\footnotetext{
${ }^{43}$ Companies Act, s 4(1).

44 (3 December 2013) 695 NZPD 15118.

${ }^{45}$ Laura Mills “Coal company sentenced for Pike River deaths” New Zealand Herald (New Zealand, 5 July 2013) < nzherald.co.nz>.
} 
onerous and therefore harmful to businesses. ${ }^{46}$ In addition, it would be difficult for Parliament to devise a concise set of rules for determining what level of insurance coverage is mandatory. The potential formula would have to take into account the type of industry and the level of danger involved. An assessment of individual circumstances may also be relevant as various entities could have different levels of health and safety control. Using these qualitative characteristics to develop a quantitative figure would be controversial. Parliament could expect a range of submissions from interested parties.

\section{B Altering the Order of Pari Passu}

Another potential solution would be for legislation to change the order of pari passu. This refers to the order in which unsecured assets are paid out to creditors during liquidation. The various creditors are ranked and the company's remaining assets are divided according to this order. ${ }^{47}$ The order is found in Schedule 7 of the Companies Act 1993. It consists of the following: liquidator, employees, Internal Revenue Department, unsecured debts, subordinated debts, preferential shares, and finally ordinary shares. Once an entire level within the ranking has been compensated, the next level can be paid. Once the remaining assets are depleted, all levels below receive nothing.

Reparation could be given greater priority within the ranking system and this may make the company more capable of paying these orders. However, there are two significant issues with this approach. Firstly, it would give deserving creditors such as the liquidator and employees less priority. It is important to incentivise the role of the liquidator by ensuring this person receives compensation. ${ }^{48}$ Also, employees are not involved in management failures so it would be unfair not to pay them for their contributions. ${ }^{49}$ Secondly, in addition to these injustices, the shareholders are likely to already be left with nothing as they are at the bottom of the ranking. Therefore adding a new creditor has the potential to leave their level of compensation unaltered and as such, it may not provide an effective deterrent. Altering the order would, however, promote reparation as it is likely to offer a higher level of compensation to the victim(s). Despite the lack of deterring value, giving the reparation order

\footnotetext{
46 Joseph Stiglitz and Carl Walsh Principles of Macroeconomics (4th ed, WW Norton \& Company, United States of America, 2005) at 77-80.

${ }^{47}$ Companies Act, s 312 and 313.

${ }^{48}$ Paul Heath and Mike Whale Insolvency Law in New Zealand (2nd ed, LexisNexis, Wellington, 2013) at 362363.

${ }^{49}$ At 363.
} 
greater priority at least ensures victim(s) receive some form of payment. This measure therefore focuses more on restitution as opposed to other aims of sentencing.

\section{Imposing Financial Penalties in Order to Shame the Company}

Another solution could be that financial penalties are imposed with a shaming effect in mind, rather than an expectation that the amount should always be paid in full. Using this approach, a court can impose a quantity deemed adequate to punish the corporation. The company can then apply to the court, stating their financial incapacity to pay and the court can opt to waiver part or all of the penalty based on the company's financial position. This could provide some level of deterrence as the amount of the original penalty can be made public. The imposition of such penalties could be an effective sentencing option as it still labels and stigmatises the corporation as criminal. ${ }^{50}$

However, there are some issues inherent in this approach. This method could undermine the credibility of the sentencing court as it shows other convicted entities that they may not have to adhere to the sentence imposed. In addition, it does not provide a substantive solution to the problem of insolvency as these companies still do not have to factually pay the full amount. Victims still do not receive the amount of reparation that is due. The punishment may also fail to provide adequate deterrence as companies with a low wealth base know they can avoid harsh financial penalties.

Additionally, it is arguable that this approach is inconsistent with legislative intention. Under section 41 of the Sentencing Act 2002, the court must consider the offender's financial capacity to pay when imposing any fines. This requirement has also been followed in subsequent case law. ${ }^{51}$ Therefore, it could be argued that the wording of this provision and later precedent indicate this type of sentencing practice is unacceptable.

However, there is an argument to be made that the offender's financial capacity is only a relevant factor and is not a mandatory consideration. The wording of section 41(2) states that if the court is uncertain about the offender's ability to pay the fine, "the court may direct the offender to make a declaration as to his or her financial capacity”. Therefore, based on the

${ }^{50}$ Eric Rasmusen, above n 15, at 521.

${ }^{51}$ Department of Labour v Hanham \& Philip Contractors Ltd, above n 34, at [71]-[73]. 
wording of the section, the only strict requirement is that the court be made aware of the offender's financial capacity. It is not essential to take this into account. Therefore, the courts have the ability to interpret the provision as they see fit and this sentencing option could still be feasible. As mentioned, this approach was taken by the sentencing judge in Department of Labour v Pike River Coal Ltd. ${ }^{52}$

\section{Moral Expectation That the Individuals Involved Pay}

Financial penalties could also be imposed without acknowledging the ability of the company as a construct to pay. Instead, the court could focus on pressuring the directors and shareholders to cover the penalty. In Department of Labour v Pike River Coal Ltd, Farish J encouraged the directors and shareholders to pay the compensation instead of the company. ${ }^{53}$ However, only moral pressure can be applied and this cannot be enforced as the company has a separate legal identity from the directors and shareholders. ${ }^{54}$ In addition, this kind of pressure may not be effective because there is little incentive for management to acquiesce to such a demand beyond goodwill. This is illustrated by the Pike River shareholders' response to the request of the judge: 99 percent voted against contributing to the payment. ${ }^{55}$

Also, even applying this kind of moral pressure is in stark opposition to the concept of separate legal corporate personality, which has been clearly provided for in the legislation and is grounded in policy considerations. When shareholders invest in a company, they are not expected to contribute anything more than the value of their shares. ${ }^{56}$ Thus, any approach based on holding individuals liable would be inconsistent with express legislative intention. In addition, it is important that shareholders are not held personally liable for any harm as this would deter healthy risk taking which is important to commercial growth. ${ }^{57}$ Shareholders need to be prepared to make difficult investment decisions and to take calculated risks. Therefore, any corporate conviction where the subsequent sentence was pressured on to an individual could be seen as unfair. Due to the problems involved in imposing financial

\footnotetext{
52 At [19].

${ }^{53}$ At [20].

${ }^{54}$ Companies Act, s 15

55 Thomas Mead “Shareholders deny Pike River families’ reparation” 3 News (New Zealand, 30 October 2013)

$<3 n e w s . c o . n z>$.

${ }^{56}$ Companies Act, s 15.

${ }^{57}$ Salomon v Salomon [1897] AC 22 at 25.
} 
penalties on an insolvent corporation, the court may need to look at non-financial options as well.

\section{Non-Financial Penalties}

If the court cannot impose financial penalties due to insolvency yet still wants to impose an effective sanction, there are a range of alternative penalties that could be used. These penalties could also be imposed on a profitable company in conjunction with other sanctions. This would be useful as financial penalties only provide retribution, denunciation, deterrence, and financial restitution. It would be beneficial for the court to consider rehabilitative measures and non-financial restitution as a means of effectively sanctioning the prohibited conduct and assisting the victim. These alternative sanctions were introduced by the Corporate Manslaughter and Corporate Homicide Act 2007 (England and Wales) and subsequently developed by the Sentencing Guidelines Council.

\section{A Formal Apology}

A preliminary and simple option would be that the company must issue a formal apology, expressing remorse for the systemic failures that resulted in death. ${ }^{58}$ The company must outline in detail what led to the failures and accept accountability for any positive wrongdoing or negligence. It would also be beneficial for the corporation to express some genuine remorse. ${ }^{59}$ In addition, the formal apology results in a shaming effect which should produce deterrence. The apology can provide some redress to the victim(s) and assist in their healing process. If no other sentence is effective, a formal apology can at a minimum, have some restorative impact.

Restorative justice is beneficial due to its focus on the victim, as opposed to merely holding the company accountable. There can be some attempt to repair the harm that has been caused. ${ }^{60}$ This can promote the victim's recovery. ${ }^{61}$ In addition, a formal apology may be more effective than financial reparation in the sense that the corporation must express

\footnotetext{
58 See also “Apology for Pike River families, manslaughter charge considered” 3 News (New Zealand, 6 November 2012) <3news.co.nz>.

${ }^{59}$ Rajesh Chhana and others, above n 40, at 9-10.

${ }^{60}$ Andrew Ashworth, above n 28, at 584-585.

${ }^{61}$ Rajesh Chhana and others, above $n$ 40, at 8.
} 
genuine guilt and regret. This could help to repair emotional damage more effectively than receiving any material benefit such as a share of the company's profit.

\section{B Publicity Order}

A second option is that the company must issue a publicity order ${ }^{62}$ The company must give a public announcement which outlines the fact of conviction, specified particulars of the offence, the amount of any fine, and the terms of the remedial order. This allows the public to understand what has happened, thereby producing bad publicity. The aim of this order should be both general and specific deterrence. Business should suffer if the company is forced to openly admit their negligence led to serious harm. The value of any trademark and goodwill is also likely to diminish. ${ }^{63}$

Another advantage of a publicity order stems from the reliance sentencing courts need to place on social stigma rather than substantive penalty. This ties back to the idea that traditional sanctions for offending that focus on deprivation of liberty cannot be applied to a company. In addition, the imposition of a financial penalty may also be inadequate if the company has a large profit base or is insolvent. Therefore, an alternative such as a publicity order could provide an effective mechanism for stigmatising and labelling the corporation as a criminal.

However, the effectiveness of this order may be limited in two key ways. Firstly, there is likely to already be a large amount of media scrutiny and public outcry following corporate offending (especially in cases involving a loss of life). ${ }^{64}$ Therefore, it is arguable that a publicity order does not add anything substantive to the company's situation. However, when a company issues such an order, they are forced to acknowledge the harm caused and take full responsibility. Therefore, a publicity order could be a useful mechanism to promote accountability.

Secondly, the effectiveness of the publicity order may be limited by the ability of the company to rebrand following a conviction for a serious offence. This problem arises from

\footnotetext{
${ }^{62}$ Corporate Manslaughter and Corporate Homicide Act, s 10.

63 Richard J Varey and others New Zealand Law for Marketers (LexisNexis, Wellington, 2009) at 87-111.

${ }^{64}$ See also "Pike River ruling proves need for corporate manslaughter law - unions" ONE News (New Zealand, 5 July 2013) <tvnz.co.nz>.
} 
another significant difference between the natural and legal person: the legal person is artificial and can easily be redesigned or dissolved. ${ }^{65}$ For example, following the sinking of the MS Herald of Free Enterprise, the company involved changed its name and repainted all of the ships in their fleet. ${ }^{66}$ It could be advantageous to introduce a corollary to this order: that the company cannot rebrand in any substantial way until a set period of time has passed. To refine this rule, the courts would need to indicate what "substantial" meant and Parliament would need to set an adequate time period for prohibition. However, this restriction on intellectual property could also be controversial as it limits freedom to use personal property in a significant way. ${ }^{67}$

\section{Remedial Order}

A final option could be to give the company a remedial order prior to sentencing, ordering them to remedy specific failures. ${ }^{68}$ As the formal apology outlines what failures led to the loss of life, the company can then use this to provide remedies. Once the company has successfully done this, the court may view their actions as a mitigating factor at sentencing. This order is unique in that it focuses heavily on rehabilitation. An order with a rehabilitative purpose is advantageous as it seeks to eliminate the failures which led to the conviction and ensure it does not happen again. ${ }^{69}$ The courts also have to address the level to which the failure has been redressed. The current legislation specifies that employers must take "all practicable steps" to ensure potential harm is managed. ${ }^{70}$ Therefore all health and safety precautions are a question of degree and need to be considered on an individual basis. ${ }^{71}$

\section{Limited Effectiveness of Non-Financial Penalties}

These penalties may not be effective in cases where the company is insolvent. This is particularly problematic as non-financial penalties are primarily aimed at insolvent corporations. A primary issue is that there may be no adequate enforcement mechanism. In

\footnotetext{
65 Trade Marks Act 2002, sections 9 and 10.

${ }^{66}$ Monopolies and Mergers Commission Report into the Merger of P\&O and European Ferries Group Plc (Department for Business, Innovation and Skills, December 1986).

67 JT International SA v Commonwealth of Australia [2012] HCA 43 at [193].

${ }^{68}$ Corporate Manslaughter and Corporate Homicide Act, s 9.

${ }^{69}$ Kaye McLaren Reducing Reoffending: What Works Now (Department of Justice, Wellington, 1992) at 20.

${ }^{70}$ Health and Safety in Employment Act 1992, s 2A.

71 “Taking all Practicable Steps” (July 2011) Department of Labour < dol.govt.nz>.
} 
the United Kingdom, the legislation specifies that failure to comply with either a publicity order or a remedial order is a separate offence and incurs a financial penalty. ${ }^{72}$ However, this system of enforcement is ineffective in cases of insolvency as the company is unable to pay this penalty. Thus, there is no motivation for an insolvent company to comply with any of the orders.

Secondly, the company needs to have the resources to adhere to the penalties imposed. The formal apology and publicity order both involve some expenditure as the company must investigate what failures led to death. Therefore, these options are still financial in nature, albeit indirectly. Likewise, compliance with a remedial order is very costly. If the company is insolvent, then they are unlikely to have the resources to complete these requirements efficiently and effectively. In addition, if the company is already insolvent and unlikely to pay any financial penalties, the effectiveness of offering a mitigating factor at sentencing is limited. The court needs to rely on moral pressure and public demand, which may be insufficient when a request of such high expenditure is made.

Thirdly, the company might no longer continue to trade following the conviction, so there is no specific deterrence involved in any of the non-financial penalties. If the company is due to be liquidated and dissolved, there is no deterrent when a formal apology or publicity order is issued. The negative public reaction does not make a difference to the profits of the company, as these are already zero following dissolution. In addition, there is no point in issuing a remedial order if the company is going to cease trading, as the harm is already prevented. This was the case for Pike River Coal Ltd, which was placed into receivership in 2010 and has since been on an indefinite trading halt. ${ }^{73}$ These issues are indicative of the problem inherent in penalising a company for any crime where the company plans to dissolve and cease trading. It may be best to reserve prosecution for cases where the company has expressed a plan to continue operation, as there is little public interest in prosecuting a corporation in liquidation. However, this option is still problematic as a convicted company in liquidation is able to avoid any liability or sanction.

\section{Imposition of Penalties on Individuals}

\footnotetext{
${ }^{72}$ Corporate Manslaughter and Corporate Homicide Act, ss 9(5) and 10(4).

${ }^{73}$ Gyles Beckford "NZ Oil \& Gas places Pike River Coal in receivership” Reuters (Wellington, 13 December 2010) <reuters.com>.
} 


\section{A Jurisdiction}

Due to the problems involved in sanctioning the company as a whole, it is practical for the courts to consider sentencing the individual managers involved. This method reverts the sentencing process back to an individual level and could be more effective as the justice system is based on this personal approach. The court could use both financial and nonfinancial penalties to sanction the individuals involved. Proposals will focus on a legal expectation that the individuals involved will pay and a ban on being involved in future management. Some academics have recommended the imposition of a term of imprisonment, ${ }^{74}$ but this is beyond the scope of this paper.

A preliminary issue here is ascertaining whether the courts have jurisdiction to sanction individuals involved in corporate management. In England and Wales, section 18 of the Corporate Manslaughter and Corporate Homicide Act 2007 specifies that no individual can be guilty as a party to a corporate offence. However, this legislation does not specifically prohibit the imposition of a sanction against an individual involved in managing a convicted company. Therefore, even if New Zealand were to adopt a model based on this foreign legislation, there may be some scope for individual sanction.

When the issue of sentencing individuals within a corporation following the conviction of the entity as a whole arises, it is important to firstly distinguish between the role shareholders and directors play within the enterprise. The shareholders act as the owners of the company while the directors manage its operations. There is separation of these two functions. ${ }^{75}$ The shareholders have very limited control over the actions of the directors. ${ }^{76}$ Therefore, it is only feasible to punish directors, as they are the only true actors who can control the company's functions. This fits with Cooke J's “doctrine of identification" principle as the courts must identify which individuals are controlling the corporation. ${ }^{77}$

\footnotetext{
${ }^{74}$ Sarah-Lee Stead and Nora Taefi “Should New Zealand Introduce Corporate Manslaughter?” ISN Magazine (July 2012).

${ }^{75}$ Henry Hansmann, Reineir Kraakman and Richard Squire “Law and the Rise of the Firm” (2006) 119 Harvard Law Review 1333 at 1336-1337.

${ }^{76}$ Companies Act, ss 165, 169, 170, 171, 172, 173 and 174.

${ }^{77}$ Nordik Industries v Inland Revenue Department [1976] 1 NZLR (SC) at 199.
} 
It could be seen as unfair to punish individuals when the corporation as a whole was convicted. This is because the blame was attributed to the entire company as no one person's actions could be found to be a substantial cause of death. Therefore, it is arguable that finding a series of systemic failures to be the problem would prohibit individual sanction. However, if individual accountability can be proven, it may be more acceptable. A practical approach would be to hold the company liable as a whole, but sanction individuals when it can be proven that their conduct contributed to the harm. This causative link is an additional element for the prosecution to prove before individuals can be sanctioned without a personal conviction. The proof of this subsidiary element is essential to the imposition of sentences against individuals. If a system was developed whereby the corporation as a whole was to be convicted beyond reasonable doubt, but the involvement of the specific individual sanctioned only had to be proven on the balance of probabilities, this could overcome the inability to find an individual guilty. The justification for using the civil burden in this context is analysed later in this Part.

\section{B Legal Expectation That the Individuals Involved Pay}

A primary option could be to impose financial penalties on the directors involved. Directors owe certain fiduciary duties to the company and can be personally liable for any breaches. ${ }^{78}$ Therefore, if the entity as a whole is convicted of an offence, the sanctions may be able to be placed on the individual directors responsible. Despite the problems with jurisdiction to impose financial liability directly onto individuals, there is some scope for this in the current legislation.

Under section 135 of the Companies Act 1993, directors breach their duties when they allow a "substantial risk of serious loss" to the company's creditors. Thus, the courts have found that directors can be individually liable when there is illegitimate risk-taking. ${ }^{79}$ Under section 301 of the 1993 Act, the court may order a negligent director to pay a certain amount during the course of liquidation. Thus, there is the possibility to impose financial penalties on individuals. ${ }^{80}$ Utilising this section also avoids the problem of directors being unable to take calculated risks. As long as the choices made by directors are reasonably viable, there is no

\footnotetext{
${ }^{78}$ Companies Act, ss 131, 132, 133, 134, 135, 136, 137 and 301.

${ }^{79}$ Mason $v$ Lewis [2006] 3 NZLR 225 at [48].

${ }^{80}$ Ross Grantham and CEF Rickett (eds), above n 21, at 108-115.
} 
finding of fault. This encourages directors to exercise due diligence and care while promoting healthy risk-taking.

Parliament may choose to use this legal expectation of behaviour for corporate offending as well. The legal precedent for a breach of section 135 is set at a high threshold. ${ }^{81}$ An appropriate sentencing provision for corporate offending could be that financial penalties are imposed directly on individuals following an entity's conviction for a criminal offence when directors can also be found to be in gross breach of the duties owed to the company. By imposing this kind of individual liability, the court could ensure any financial penalties are paid. This also means shareholders still have limited liability and as such, it should not hinder healthy business investment. It is not a viable argument to say this deters viable business risktaking because directors are concerned about facing personal liability. To avoid this problem, the courts can continue to apply this kind of personal liability only when the negligence reaches a very high standard. ${ }^{82}$

\section{Ban directors from Managing another Company}

Another form of individual sentencing for corporate offending would be to impose individual non-financial penalties straight onto the directors. There is scope within the current legislation for the imposition of this type of individual liability as well. Under section 385 of the Companies Act 1993, an individual director may be banned from managing another company for a period of up to ten years. ${ }^{83}$ This can be done if three conditions are met. Firstly, the directors' company must be insolvent. Secondly, the Registrar of Companies or Financial Markets Authority must be satisfied that the director has been involved in mismanagement. Thirdly, there must be a causal link between this mismanagement and the insolvency. ${ }^{84}$ The legislative precedent from this section could be used to develop a set of rules around punishing individual directors for corporate offending in a comparable way.

The object of the current legislative provision is to protect the public from future mismanagement. ${ }^{85}$ Therefore, the aims of the sanction include both deterrence and

\footnotetext{
${ }^{81}$ Peter Watts and others Company Law in New Zealand (LexisNexis, Wellington, 2011) at 605-609.

${ }^{82}$ At 594-598.

${ }^{83}$ Subsection 3.

${ }^{84}$ Subsection 4.

85 “Banned directors” (16 August 2013) Companies Office <business.govt.nz>.
} 
incapacitation. The capacity for this sanction to incapacitate a responsible director is unique in the sense that it fully prevents liable directors from being involved in the management of another company. This promotion of public welfare would be a key advantage of introducing some kind of individual non-financial liability following the conviction of a corporation.

\section{Burden of Proof}

The potential for individual sanction raises the issue of to what standard the prosecution must prove the subsidiary element (the individual's actions were a cause of the offence). Proceedings are brought against the corporation because the actions of no single individual can be established beyond reasonable doubt as the operative cause of the offence. Therefore, the civil standard needs to be used in order to impose sanctions on the individuals.

This issue should first be analysed with reference to the current legislation, as this shows legislative intention in this area. Section 385 states that such an order can be made if the relevant authority is "satisfied" the director was responsible for the problem. This indicates the burden of proof in the current legislation is based on a lower standard than the criminal one of beyond reasonable doubt. ${ }^{86}$ The wording of section 135 contains no guidance as to burden of proof, but in subsequent cases, the civil standard has been used. ${ }^{87}$ In addition, both offences are civil in nature, which implies the balance of probabilities is appropriate. On the other hand, while both section 135 and section 385 are civil in nature, they are used as a basis for expanding liability for individual directors to a criminal (as well as civil) area. Therefore, the criminal standard may need to be used. ${ }^{88}$ However, a rational counter-argument to this proposition is that the individuals are not being convicted of an offence, penalties are merely be applied. Therefore, the proposed changes could be conceptualised as more civil in nature than criminal.

\section{Recommendation for Reform}

Following this discussion of the various sentencing options that should be considered, it is helpful to analyse which mechanisms should actually be implemented. The reform should

\footnotetext{
${ }^{86}$ Davidson v Registrar of Companies [2011] 1 NZLR 542 at [98]-[99].

${ }^{87}$ Mason v Lewis, above n 79, at [50]-[51].

${ }^{88}$ Woolmington v DPP [1935] UKHL 1.
} 
focus on the development of coherent standards as this will reduce judicial discretion and lead to more consistent sentencing outcomes. It is appropriate to follow the approach in the United Kingdom and use the imposition of a financial penalty as the starting point. The quantum of any financial penalty should be determined with reference to established rules. The focus should be on reparation orders rather than fines because these orders offer compensation to the victim(s). Reparation can focus both on punishing the offender and on remedying the harm. ${ }^{89}$ In determining the totality of any penalty, the court should consider the nature of the offence, then the seriousness of the offence, before finally applying relevant aggravating and mitigating factors. A particularly severe penalty should be imposed in cases involving a loss of life. There needs to be a severe deprivation of material benefit in order to compare to a term of imprisonment. In addition, the court should factor in the size of the company as this will mitigate the problems surrounding a wealthy company effectively being able to break the law. A large discrepancy in penalties will be appropriate in these circumstances.

Reform in this area will also need to centre on mechanisms to overcome the issue of insolvency. A primary recommendation is the implementation of mandatory life insurance coverage. This proactively avoids any problems with a corporation's inability to pay and should be an effective measure alone. The order of pari passu should not be altered as it is important that deserving creditors such as the liquidator and employees receive compensation. In addition, there should be no financial penalty imposed where the company is unable to pay as this both undermines the sentencing court and places undue pressure on shareholders to contribute.

It is important that all three non-financial penalties are used. This is due to their varying focuses. While all of these penalties have a broad application, the primary emphasis of the formal apology is on the victim, the publicity order focuses on the offender, and the remedial order seeks to benefit the broader community by protecting from future harm. Therefore in every case, a formal apology, publicity order, and remedial order should be imposed. As mentioned, these measures may have limited effectiveness when the company ceases to trade following conviction. However, it is still appropriate to apply them for the restorative benefit and deterrent value.

${ }^{89}$ Kathleen Daly "Restorative justice: The real story” 4 Punishment \& Society 55 at 78. 
In addition, the legislature should consider imposing financial and non-financial penalties directly onto the individuals responsible if some causation can be shown between their actions and the resulting harm. This ensures financial penalties can be paid and protects society by preventing negligent directors being involved in future mismanagement. The measure is also beneficial as it guarantees individual directors cannot become immune from sanction on the basis that they were acting for a company at the time of the offending.

\section{A Application of Law Reform}

Each case ultimately needs to be decided on its facts. Therefore, it is useful to consider ways these mechanisms could be applied to the sentencing case of Department of Labour v Pike River Coal Ltd. These proposed reforms could be effective if a situation like the Pike River disaster ever reoccurred. In that case, the company had entered insolvency and would cease to trade following the imposition of sentence. Therefore, the obligation to pay a financial penalty would be prima facie inadequate. The primary mechanism to overcome insolvency (mandatory life insurance coverage) could have been utilised as the company did not have satisfactory coverage. If this requirement was mandatory, the company would have been in a better position to pay the reparation order and fine.

The court could then consider non-financial options. A formal apology and publicity order would force the company to take responsibility for the failures that led to death and would have an emotional and restorative benefit for victims. However, both a publicity order and a remedial order would serve little purpose as the company was going to cease operations following sentencing.

The final option for the court would be to impose some kind of individual sanction on the responsible directors. During the course of the litigation, the Chief Executive Officer, Peter Whittall, was charged with 12 health and safety violations. These charges were later dropped due to insufficient evidence and the court was unable to impose any sanction directly against this individual. ${ }^{90}$ An additional aspect of sentencing for corporate offences could be the ability to punish the natural persons responsible. This should only be done when some

${ }^{90}$ Kurt Bayer “Charges dropped against ex-Pike River boss Peter Whittall” New Zealand Herald (New Zealand, 12 December 2013) <nzherald.co.nz>. 
individual accountability is attributable. ${ }^{91}$ If the lesser standard of the balance of probabilities was used to sanction individuals involved in a convicted corporation, some kind of penalty may have been available for certain directors. This could firstly involve requiring directors to pay the financial penalties from their own personal wealth, which would promote deterrence and ensure families receive compensation. In addition, directors could be prohibited from being involved in corporate management for a specified period of time, which would protect the public.

For this case, an appropriate outcome would be a formal apology to the families of the victims. To provide material compensation, this order could be combined with some kind of individual financial liability for certain managers. In addition, responsible directors could be barred from future corporate management to protect the public. Analysis of this situation shows how cases need to be examined on an individual basis.

\section{Conclusion}

Criminal law generally focuses on convicting and sentencing human beings for wrongful conduct. However, corporations can and do still cause harm. The justice system needs to find a way to effectively penalise corporate conduct. As this paper has discussed, the issues present in corporate liability cases are not limited to only problems with conviction. Following a finding of guilt, it can still be difficult to impose an effective sentence on a corporation, particularly in cases involving the highest level of harm: loss of life. Due to the artificial nature of a corporation, courts will need to adopt a different set of penalties and use these in conjunction. A broad range of financial and non-financial penalties should be available at both the corporate and individual level.

Sentencing courts should focus on adopting a basic methodology in order to apply sanctions consistently. Consideration should first be given to the imposition of a financial penalty and the company's ability to pay this should be assessed. Focus should then shift to non-financial options. The court can use these penalties either in conjunction with a financial order (to achieve a broader range of sentencing aims) or in isolation (if an insolvent corporation cannot afford to pay). Finally, the court needs to determine whether individual sanction is

\footnotetext{
${ }^{91}$ Companies Act 1993, ss 135 and 385.
} 
appropriate by considering the level of personal involvement of directors. With this creative new variety of options, effective corporate sentencing can be possible.

X Bibliography

\section{A Cases}


$1 \quad$ New Zealand

Department of Labour v Hanham \& Philip Contractors Ltd (2008) 6 NZELR 79 (HC).

Department of Labour v Pike River Coal Ltd [2014] DCR 32.

Mason v Lewis [2006] 3 NZLR 225.

Meridian Global Funds Management Asia Ltd v Securities Commission [1994] 2 NZLR 291.

Mobile Refrigeration Specialists Ltd v Department of Labour (2010) 7 NZELR 243 (HC).

Nordik Industries v Inland Revenue Department [1976] 1 NZLR (SC).

$R v$ Taueki [2005] 3 NZLR 372 (CA).

$2 \quad$ Australia

JT International SA v Commonwealth of Australia [2012] HCA 43.

$3 \quad$ England and Wales

Lennards Carrying Co v Asiatic Petroleum [1915] AC 713.

$R v$ Friskies Petcare (UK) Ltd [2000] 2 Cr App R (S).

$R v$ Howe and Sons (Engineers) Ltd [1999] 2 All ER 249.

$R$ v Milford Haven Port Authority [2000] 2 Cr App R (S) 423.

$R$ v P \& O Ferries (Dover) Ltd [1991] 93 Cr App R (S) 72 (Herald of Free Enterprise).

Salomon v Salomon [1897] AC 22.

Tesco Supermarkets Ltd v Nattrass [1971] UKHL 1.

Woolmington v DPP [1935] UKHL 1.

\section{B Legislation}

Companies Act 1993.

Corporate Manslaughter and Corporate Homicide Act 2007 (England and Wales).

Crimes Act 1961.

Criminal Justice Act 2003 (England and Wales).

Criminal Procedure Act 2011.

Health and Safety in Employment Act 1992. 
Life Insurance Act 1908.

Sentencing Act 2002.

Summary Proceedings Act 1957.

Trade Marks Act 2002.

\section{Books and Chapters in Books}

Andrew Ashworth Principles of Criminal Law (6th ed, Oxford University Press, Oxford, 2009).

Celia Wells Corporations and Criminal Responsibility (2nd ed, Oxford University Press, 2001).

Clinton Alley and others New Zealand Taxation 2013 - Principles, Cases and Questions (Thomson Reuters, Wellington, 2013).

Jeremy Hubbard, Cordelia Thomas and Sally Varnham Principles of Law for New Zealand

Business (5th ed, Pearson Education NZ Ltd, Auckland, 2012).

John Farrar (ed) Company and Securities Law in New Zealand (Brookers, Wellington, 2008).

John McDermott Understanding Company Law (LexisNexis, Wellington, 2011).

Joseph Stiglitz and Carl Walsh Principles of Macroeconomics (4th ed, WW Norton \& Company, United States of America, 2005).

Kaye McLaren Reducing Reoffending: What Works Now (Department of Justice, Wellington, 1992).

Morag McDowell and Duncan Webb The New Zealand Legal System (Butterworths, Wellington, 1995).

Paul Heath and Mike Whale Insolvency Law in New Zealand (2nd ed, LexisNexis, Wellington, 2013).

Paul Sumpter Intellectual Property Law: Principles in Practice (CCH Limited, New Zealand, 2006).

Peter Watts and others Company Law in New Zealand (LexisNexis, Wellington, 2011).

RB Whittingham The Blame Machine: Why Human Error Causes Accidents (Elsevier Butterworth-Heinemann, United Kingdom, 2004).

Richard J Varey and others New Zealand Law for Marketers (LexisNexis, Wellington, 2009).

Ross Grantham and CEF Rickett (eds) Corporate Personality in the 20th Century (Hart Publishing, United Kingdom, 1998). 
Silvana Schenone Duties and Responsibilities of Directors and Company Secretaries in New Zealand (4th ed, CCH New Zealand, Auckland, 2011).

Stephen Ross, Randolph Westerfield and Jeffrey Jaffe Corporate Finance (10th ed, McGrawHill Education, United States, 2013).

\section{Journal Articles}

Andrew Ashworth "Responsibilities, Rights and Restorative Justice” (2002) 42 Brit J Criminol 578.

Eric Rasmusen "Stigma and Self-Fulfilling Expectations of Criminality” (1996) 39 Journal of Law and Economics 519.

Henry Hansmann, Reineir Kraakman and Richard Squire "Law and the Rise of the Firm” (2006) 119 Harvard Law Review 1333.

Kathleen Daly “Restorative justice: The real story” 4 Punishment \& Society 55.

\section{E Parliamentary Materials and Government Publications}

(3 December 2013) 695 NZPD 15118.

Monopolies and Mergers Commission Report into the Merger of $P \& O$ and European Ferries Group Plc (Department for Business, Innovation and Skills, December 1986).

Royal Commission on the Pike River Coal Mine Tragedy Final Overview: Volume 1 (Department of Internal Affairs, October 2012).

Royal Commission on the Pike River Coal Mine Tragedy Final Overview: Volume 2 (Department of Internal Affairs, October 2012).

Sentencing Guidelines Council Corporate Manslaughter \& Health and Safety Offences Causing Death (February 2010).

\section{F Reports and Dissertations}

Meaghan Wilkinson "Corporate Criminal Liability- The Move Towards Recognising Genuine Corporate Fault” (LLB (Hons) Dissertation, University of Canterbury, 2003). Rajesh Chhana and others The Sentencing Act 2002: Monitoring the First Year (Ministry of Justice, March 2004). 


\section{G International Materials}

Basic principles of the use of restorative justice programmes in criminal matters ESC Res 2000/14, E/2000/99(SUPP) (2000).

\section{H Internet Materials}

“Apology for Pike River families, manslaughter charge considered” 3 News (New Zealand, 6 November 2012) <3news.co.nz>.

“Banned directors” (16 August 2013) Companies Office < business.govt.nz>.

Gyles Beckford “NZ Oil \& Gas places Pike River Coal in receivership” Reuters (Wellington, 13 December 2010) <reuters.com>.

"Introduction to the Health and Safety in Employment Act” (2010) Ministry of Business, Innovation, and Employment < dol.govt.nz>.

Kurt Bayer “Charges dropped against ex-Pike River boss Peter Whittall” New Zealand

Herald (New Zealand, 12 December 2013) <nzherald.co.nz>.

“Labour pledges compensation for Pike families” Radio New Zealand News (19 November 2013) <www.radionz.co.nz> .

Laura Mills “Coal company sentenced for Pike River deaths” New Zealand Herald (New Zealand, 5 July 2013) <nzherald.co.nz>.

“Pike River ruling proves need for corporate manslaughter law - unions” ONE News (New Zealand, 5 July 2013) <tvnz.co.nz> .

“Taking all Practicable Steps” (July 2011) Department of Labour < dol.govt.nz>. Thomas Mead “\$110,000 awarded to Pike River victims, families” 3 News (New Zealand, 5 July 2013) <3news.co.nz>.

Thomas Mead “Shareholders deny Pike River families’ reparation” 3 News (New Zealand, 30 October 2013) <3news.co.nz>.

\section{Newspaper and Magazine Articles}

Sarah-Lee Stead and Nora Taefi “Should New Zealand Introduce Corporate Manslaughter?” ISN Magazine (July 2012). 
The word count of this paper is exactly 8000 words (excluding table of contents, abstract, footnotes, and bibliography). 